\title{
MEMBANGUN BUDAYA HUKUM PANCASILA SEBAGAI BAGIAN DARI SISTEM HUKUM NASIONAL INDONESIA DI ABAD 21
}

\author{
C.F.G. Sunaryati Hartono \\ email: hartono.sunaryati@gmail.com
}

\begin{abstract}
This article discusses the weaknesses of Indonesian (internal) legal culture. The author argues that this weakness points to the attitudes, behavior, and beliefs about the proper place of law in daily life as entertained by individuals working in the government, law making institutions as well as those working in the law enforcement sector. Moreover, this internal weakness in Indonesian legal culture, poses a threat to the unity of Indonesia as a nation. One solution offered is to return to and revive the State ideology and philosophy, Pancasila, as the basis to develop a more viable and healthy Indonesian legal culture.
\end{abstract}

Keywords

Pancasila, Legal Culture, Nation

\begin{abstract}
Abstrak
Tulisan ini mengangkat persoalan lemahnya budaya hukum internal Indonesia. Disebutkan bahwa masalah utama pengembangan hukum Indonesia adalah lemahnya budaya hukum internal dari terutama orang-perorangan maupun instansi pemerintah, pembuat hukum maupun penegak hukum. Ditengarai pula bahwa hal ini menimbulkan ancaman terhadap kesatuan-persatuan bangsa Indonesia. Satu usulan terpenting adalah keniscayaan kita kembali menghidupkan budaya berhukum di Indonesia sejalan dengan falsafah bangsa dan bernegara, Pancasila.
\end{abstract}

Kata Kunci:

Pancasila, Budaya Hukum, Bangsa

\section{Pendahuluan}

Setiap tanggal 17 Agustus, Indonesia sebagai sebuah bangsa selalu memperingati dan merayakan hari ulang tahun kemerdekaan, dan saat ini Indonesia telah memasuki fase awal dasawarsa abad ke-21.

Keadaan kehidupan nasional pada masa penjajahan baik oleh bangsa Belanda maupun oleh bangsa Jepang sangat menyedihkan dan memprihatinkan. Keprihatinan bukan disebabkan karena tingkat ekonomi dan kesejahteraan bangsa yang masih lebih rendah dibandingkan dengan negara-negara tidak hanya di kawasan Asia tetapi juga di kawasan ASEAN, terlebih dari itu dikarenakan 
watak (volksgeist) dan solidaritas bangsa Indonesia pada saat ini justru semakin memburuk ${ }^{1}$.

Sementara itu dibandingkan dengan keadaan ekonomi, keamanan dan sosial di tahun 1940-an sampai dengan 1980-an, keadaan sosial, ekonomi dan keuangan nasional serta perkembangan di bidang pendidikan dan teknologi justru sangat meningkat.

Sebenarnya yang menyebabkan berkurangnya pencapaian tingkat ekonomi, keuangan dan kesejahteraan kita bukanlah karena selama 63 tahun ini ekonomi, pendidikan dan kehidupan sosial bangsa Indonesia tidak maju dan membaik, akan tetapi ketidakpuasan masyarakat atas keadaan umum Indonesia. Di satu pihak disebabkan tuntutan yang berlebihan (exploding demands), egoisme dan individualisme orang Indonesia di abad 21 ini sangat meningkat, sementara peningkatan jumlah penduduk Indonesia, yang pada waktu Proklamasi Kemerdekaan baru berjumlah 70 juta dalam sepuluh tahun terakhir meningkat secara tidak terkendali. Sehingga pada 2008 ini jumlah penduduk telah berlipat ganda menjadi 220 juta orang lebih, atau meningkat 3 (tiga) kali lipat dari saat pembentukan Republik Indonesia. ${ }^{2}$

Dari kondisi tersebut di atas, maka timbul pertanyaan: pertama, mengapa bangsa Indonesia, ketika tidak memiliki apa-apa dan hidup di bawah standar kelayakan, justru dapat menunjukkan sifat dan semangat solidaritas bangsa yang lebih besar dan moral maupun disiplin yang lebih kuat dari pada saat ini? Kedua, mengapa kaum Pemuda, khususnya Mahasiswa waktu itu mampu menggerakkan pemimpin bangsa untuk memproklamirkan Kemerdekaan Bangsa Indonesia, menyusun dan melahirkan Undang-Undang Dasar dan menuntaskan perjuangan, baik fisik maupun diplomatik, melawan Belanda, Inggris, dan Amerika? Ketiga, mengapa kini kaum Pemuda dan Mahasiswa hanya dapat memaki-maki, menyalahkan pemimpin bangsa, dan berebut kursi dan kedudukan dalam

${ }^{1}$ Harian Kompas, Jakarta, 11 Agustus 2008, hlm 1.

2 Tulisan ini adalah naskah yang ditulis oleh penulis pada tahun 2008, namun masih relevan untuk dipublikasikan pada saat ini. (Editor) 
berbagai Pemilihan Kepala Daerah (Pilkada), melalui orasi dan demonstrasi sambil menunjukkan kemarahannya dengan merusak pagar, kantor dan aset negara sampai milik pribadi orang yang kebetulan ada di dekat tempat demonstrasi diadakan, sementara mereka sendiri belum menunjukkan prestasinya, baik sebagai pembayar pajak atau sebagai pelajar/mahasiswa yang berhasil dalam studinya? Atau sebagai pekerja/karyawan yang berkualitas?

Dalam mencari jawaban atas pertanyaan tersebut di atas, hal yang pelu dilakukan adalah menelusuri pertanyaan: Mungkinkah perubahan teknologi, materi, dan kehidupan sosial yang lebih maju dan terbuka akibat kecepatan komunikasi antar-bangsa secara global itu tanpa terasa juga menimbulkan pergeseran identitas? Yaitu pergeseran dari identitas nasional ke identitas asing atau internasional, di satu pihak? Tetapi untuk orang lain atau kelompok tradisional, mereka justru mencari kebahagiaannya dari identitas nasional ke identitas lokal/kedaerahan, di lain pihak? Bilamana begitu, apakah membangun identitas dan watak atau budaya bangsa Indonesia itu (nation and character building) tidak lebih penting dari pada membangun segala aspek dan sarana fisik, seperti gedung bertingkat, pusat perbelanjaan yang mewah, bahkan juga sistem hukum, sistem ekonomi dan sebagainya, sebagaimana setiap tahun digariskan dalam Rencana Pembangunan Nasional. Bilamana benar, maka untuk membangun sistem hukum nasional, sebenarnya harus dibina suatu budaya hukum nasional terlebih dahulu yang akan mempengaruhi kekuatan dan efektivitas berlakunya dan ditetapkannya berbagai kaidah hukum nasional.

\section{Mengapa Penduduk Pribumi Penduduk Pribumi yang Mendiami Beribu Pulau Di Antara Benua Asia dan Benua Australia menjadi satu bangsa: bangsa Indonesia?}

Untuk dapat menjawab pertanyaan tersebut perlu ditelusuri kembali mengapa penduduk yang berasal dari berbagai suku dan ras itu, dan menempati 
beribu-ribu pulau di Nusantara, antara benua Asia dan Australia memutuskan menjadi satu nation, yaitu Bangsa Indonesia.

Ketika pada awal abad ke-20 para pemuda dan Tokoh Pergerakan di Nusantara ini mulai bangkit untuk membina kehidupan yang lebih baik bagi orang Indonesia menuju suatu Negara Indonesia Merdeka, Gubernur Jenderal HindiaBelanda pada saat itu Gubernur Jenderal De Graaff pada pembukaan sidang umum Dewan Rakyat (Volksraad) di Batavia bertanya 3 :

"Di mana Indonesia? Tidak ada Indonesia! Belanda-lah yang berkuasa menyatukan nusantara ini di bawah kekuasaan Pemerintah Hindia-Belanda. Bangsa Indonesia itu sama sekali tidak ada, hanya ada rakyat pribumi terdiri dari sekian banyak suku. Mereka disatukan oleh Belanda dan dicantumkan sebagai penduduk HindiaBelanda dengan berbagai tingkat warga"

Cemoohan dan hinaan Gubernur Jenderal De Graaff inilah yang menjadi tantangan dan pemicu bagi berbagai pemuda dan tokoh di berbagai daerah dari Sabang sampai Merauke untuk bangkit sebagai suatu bangsa, sebagai satu nation, sehingga Mr. Yamin mempunyai gagasan untuk mengadakan Kongres Pemuda yang Kedua pada 1928 dengan tema: "Satu Nusa, Satu Bangsa, Satu Bahasa”, dengan mempersatukan semua perkumpulan pemuda, Jong Java, Jong Sumatera, Jong Celebes, dan sebagainya ${ }^{4}$.

Dari apa yang telah diuraikan di atas, dan melihat serta mempelajari sejarah, sebenarnya tidak ada rasa Indonesia, tidak ada Volks Indonesia, tetapi yang ada adalah Nation Indonesia: suatu masyarakat yang sengaja dibentuk oleh nenek moyang kita, bukan karena adanya hubungan darah, bukan karena adanya persamaan budaya, tetapi karena adanya tekad untuk memperbaiki nasib bersama, akibat penjajahan selama berabad-abad oleh orang asing, sehingga kami merasa senasib sepenanggungan dan menimbulkan tekad meneruskan kehidupan bersama secara turun-temurun.

\footnotetext{
${ }^{3}$ Lihat Otobiografi Ben Wowor: "Seabad lingkungan saya", Manado, 2007, hlm. 1.

${ }^{4}$ Id.
} 
Oleh sebab itu bangsa Indonesia (the Indonesian nation) lahir pada 28 Oktober 1928, tidak sebelumnya dan juga tidak sesudahnya. Sehingga mestinya kita tidak hanya memperingati 17 Agustus sebagai Hari Proklamasi Kemerdekaan yang diproklamasikan oleh Soekarno-Hatta atas nama bangsa Indonesia, tetapi juga wajib memperingati setiap tanggal 28 Oktober sebagai hari kelahiran Bangsa Indonesia. Karenanya, Indonesia sebagai sebuah Bangsa belum genap berumur 100 tahun, dan baru 86 tahun saja. Suatu umur yang bagi manusia perorangan sudah relatif cukup tua, tetapi tidak bagi sebuah ukuran bangsa (nation).

Itulah sebabnya, sekalipun kita sudah beruntung untuk hidup dalam suatu ikatan kenegaraan, namun Bangsa Indonesia memang belum memiliki satu budaya nasional. Sehingga masih sangat mudah dipecahbelah, baik oleh orang asing yang mempunyai motifnya sendiri-sendiri, maupun oleh unsur-unsur tradisional dan kedaerahan yang mengira, bahwa dengan melepaskan dirinya dari ikatan Negara Kesatuan Republik Indonesia atau ikatan Nationhood Indonesia mereka dapat memperoleh kesejahteraan dan kemakmuran yang lebih cepat dan lebih jaya untuk sukunya sendiri atau untuk daerahnya sendiri. Itulah latar belakang proses "pemekaran" Daerah yang bertubi-tubi di masa reformasi ini. Padahal sudah sejak semula motto bangsa Indonesia adalah "Bersatu kita teguh, bercerai kita runtuh".

\section{Perbedaan antara Ras, Volk dan Nation}

Oratio Ernest Renan, Universitas Sorbonne, Perancis, 1889, dengan judul "Qu'est ce qu'une nation" (Apakah Nation Itu?) menjelaskan bahwa nation itu adalah "sekelompok manusia, yang sama-sama pernah mengalami penderitaan yang sangat parah, sehingga merasa senasib sepenanggungan, dan karena itu mempunyai tekad untuk terus hidup sebagai satu kelompok (le desir de vivre ensemble) di masa depan secara turun temurun"5. Oleh sebab itu pembentukan

\footnotetext{
5 Baca Ernest renan: "Apakah bangsa itu?" Oratio Dies yang berjudul "Qu'est ce qu'une nation?", terjemahan Prof. Mr. Sunario, dalam bahasa Indonesia, alumni Bandung, hlm. 54.
} 
suatu nation tidaklah berdasarkan persamaan keturunan, seperti dalam hal kelompok yang dinamakan "ras" (race). Juga tidak didasarkan pada persamaan budaya atau agama, seperti di dalam hal suatu "volk" atau "bangsa Yahudi". Tetapi pembentukan suatu nation disebabkan oleh terjadinya persamaan nasib/pengalaman bersama yang sangat berat dan menyedihkan (faktor historis) sehingga kelompok manusia itu merasa senasib sepenanggungan (faktor psikologis), dan mempunyai tekad untuk tetap hidup di dalam kebersamaan (le desir de vivre ensemble) untuk selama-lamanya secara turun temurun (faktor politik).

Dengan lain perkataan: nation Indonesia bukan terbentuk akibat persamaan keturunan atau persamaan faktor geneologis. Juga bukan terbentuk akibat persamaan agama atau budaya (faktor kultural), tetapi bangsa Indonesia itu tumbuh dan sengaja dibentuk oleh para Pejuang kemerdekaan kita akibat persamaan pengalaman penjajahan yang sangat pahit (faktor sejarah) sehingga menimbulkan rasa persatuan dan senasib sepenanggungan (faktor psikologis) dan ingin bersama-sama tetap menyamakan nasib bersama ini dengan sama-sama berjuang dan memperjuangkan kemerdekaan bersama, demi mencapai keadilan sosial, kesejahteraan dan kecerdasan bersama sebagai suatu bangsa (one nation) di antara bangsa-bangsa lain di dunia (faktor politik nasional, maupun internasional).

\section{Perbedaan Hukum Positif dan Hukum Nasional}

Sejalan dengan arti nation, yang berbeda dengan arti "ras", dan "volk", maka ada perbedaan besar antara hukum positif dan hukum nasional. Sebagaimana diketahui akhiran "al" dibelakang kata benda, mengubah kata benda itu menjadi kata sifat, sehingga nasional berarti sesuai dengan cita-cita atau nilai-nilai nation (Indonesia), atau diperuntukkan atau berlaku bagi seluruh nation Indonesia, atau berlaku di seluruh wilayah negara Republik Indonesia. 
Jelas bahwa hingga saat ini belum seluruh hukum positif Indonesia (sebagai hukum yang berlaku di wilayah Indonesia pada saat ini), sudah merupakan hukum nasional, yang didasarkan dan bernafaskan cita-cita bangsa sebagaimana diutarakan dalam Undang-Undang Dasar 1945.

Jan Michiel Otto ${ }^{6}$ (dari Belanda) dan almarhum Daniel Lev7 (dari Amerika Serikat), yang sangat lama mempelajari sejarah maupun sosiologi hukum negaranegara berkembang, termasuk Indonesia, mengemukakan, bahwa Indonesia seperti banyak negara berkembang lain, hingga kini sebenarnya belum memiliki suatu sistem hukum nasional.

Menurut Michiel Otto pada umumnya hukum di negara-negara berkembang terdiri dari 4 (empat) lapis. Lapisan yang paling dalam terdiri dari kaidah-kaidah hukum kebiasaan/adat. Di atasnya terdapat kaidah-kaidah agama. Di atasnya lagi ditemukan kaidah-kaidah hukum kolonial dan lapis teratas dibangun hukum nasional modern yang semakin banyak kaidah dan lembagalembaganya.

Akan tetapi dalam lima dasawarsa terakhir (dalam rangka globalisasi) di atas lapisan hukum nasional itu terdapat sejumlah konvensi-konvensi dan kaidahkaidah serta lembaga dan pranata hukum internasional. ${ }^{8}$

Hubungan antara lapisan hukum yang satu dengan lapisan yang lain berbeda dari negara satu ke negara lain. Akan tetapi dikeluhkan oleh Michiel Otto, bagaimanapun juga masalah yang terbesar yang dialami di dalam praktek, adalah bahwa sistem hukum beraneka-warna ini tidak berfungsi sebagaimana mestinya, sehingga dalam kehidupan sehari-hari terjadi ketidakpastian hukum.

Sebab-sebab ketidakpastian hukum itu terletak pada faktor-faktor yuridis maupun faktor-faktor non yuridis. ${ }^{9}$ Tetapi bagaimanapun juga, akibat adanya

\footnotetext{
6 Jan Michiel Otto dalam pidato pengukuhannya sebagai Guru Besar yang berjudul: Reele Rechtszekerheid in Ontwikkelingslanden, Universiteit Leiden, 2000.

7 Baca Daniel Lev: "Judicial Institutions and Legal Culture in Indonesia”, dalam buku Claire Holt: Culture and Politics in Indonesia, Equinox Publishing, Jakarta, hlm. 248.

8 Supra No. 5, hlm. 1.

9 Supra No. 5, hlm. 4.
} 
perbedaan yang sangat besar antara kenyataan (das sein) dan norma hukumnya (das sollen), dapat dikatakan bahwa negara-negara berkembang belum benarbenar merupakan negara hukum. ${ }^{10}$ Hal inilah yang sangat menyulitkan penyelenggaraan pemerintahaan (bestuur) di negara-negara berkembang, karena penegakan hukum yang benar, sesungguhnya merupakan suatu pra-kondisi untuk mencapai hampir semua tujuan pembangunan, seperti keamanan, pembangunan ekonomi, demokratisasi, pemeliharaan lingkungan dan sebagainya. ${ }^{11}$

Bahkan, menurut Michiel Otto, kalau saja lembaga-lembaga hukum dan profesi hukumnya tidak berfungsi sebagaimana mestinya, sesungguhnya sudah terjadi ketertinggalan (achterstand, Belanda). Lebih lanjut, Michiel Otto mengemukakan 3 (tiga) macam faktor yang mempengaruhi kepastian hukum yang nyata, yaitu: kaidah hukum itu sendiri; lembaga-lembaga hukum itu sendiri; dan lingkungan masyarakat yang bersangkutan, khususnya faktor-faktor politik, ekonomi dan sosial budaya. Namun berdasarkan pengalaman yang dialami oleh penulis, secara empiris sesungguhnya ada jauh lebih banyak faktor yang mempengaruhi kepastian hukum yang nyata itu.

Faktor-faktor yang mempengaruhi, selain dari apa yang telah disampaikan oleh Michiel Otto antara lain, tingkat kecerdasan dan kejujuran (integritas) para pelaku/pejabat lembaga-lembaga hukum; sarana dan pra-sarana yang digunakan oleh lembaga-lembaga hukum; tingkat kinerja; koordinasi dan sinkronisasi antara lembaga-lembaga hukum (baik lembaga legislatif, eksekutif, yudikatif dan pengawasan); tingkat teknologi yang digunakan oleh lembaga-lembaga dan profesi hukum; standard operating procedures, gaya manajemen (kuno atau modern) yang digunakan oleh pelaku hukum dan pemberi layanan hukum; tolok ukur norma untuk mengukur kinerja dan profesi pejabat dan profesi hukum (good

10 Supra, No. 5, hlm. 5 .

11 Id, hlm. 4. 
governance); dan last but not least, besar kecilnya anggaran belanja yang disediakan/disisihkan untuk pembangunan dan reformasi hukum. ${ }^{12}$

Bagaimanapun juga hingga kini Hukum Positif kita masih juga terdiri dari 5 (lima) lapisan hukum yang beraneka-warna dan aspirasinya juga berbeda-beda dan kadang-kadang bahkan bertolak belakang. Jika hukum adat ingin mempertahankan eksistensi masyarakat adat, maka hukum agama bertujuan untuk memprioritaskan berlakunya kaidah-kaidah agama tertentu, sementara itu hukum nasional ingin memperkuat kehidupan berbangsa sebagai bangsa Indonesia dan bernegara dalam Negara Kesatuan Republik Indonesia. Hukum Internasional ingin menghapus semua negara bangsa (nation state) di dunia agar semua orang hanya menjadi warga dunia di bawah kekuasaan negara yang paling adi daya.

Tampaklah betapa sulitnya bangsa kita mempertahankan identitas keIndonesia-an, di bawah sistem hukum yang masih beraneka-ragam dan berlapislapis, dan semakin pluralistis dan saling berbentrokan kepentingannya.

Karena itu, jika hal ini benar-benar tidak kita inginkan, dan apabila benarbenar kita bertekad mempertahankan identitas kita sebagai sebuah bangsa di abad-abad yang akan datang, dan benar-benar tetap ingin mempertahankan kemerdekaan yang kita peroleh dengan nyawa, darah dan air mata dari beriburibu pejuang kemerdekaan dan korban revolusi kemerdekaan, tidak ada jalan lain dari pada sikap tetap setia pada nilai-nilai Pancasila yang telah menjadi tali pengikat bangsa ini, yang di masa yang akan datang benar-benar harus kita jiwai dan terapkan sebagai volksgeist Indonesia, baik di dalam setiap tindakan kehidupan berbangsa dan bernegara, maupun di dalam kehidupan pribadi kita sehari-hari.

Mungkin juga masih perlu ditambahkan perlunya sikap kerja keras, disiplin, jujur dan menepati janji (pacta sunt servanda) serta senantiasa menjaga

12 Bandingkan Sunaryati Hartono: Bhineka Tunggal Ika sebagai Asas Hukum Bagi Pembangunan Hukum Nasional, Citra Aditya Bakti, Bandung, 2006, hlm. 44-53. 
keseimbangan, keharmonisan, kepatutan, dan sopan santun dalam pengambilan keputusan maupun proses negosiasi menuju permufakatan, sebagaimana dituntut dari setiap orang maupun bangsa yang adil dan beradab.

\section{Nilai-Nilai Pancasila sebagai Nilai-Nilai Universal}

Sudah banyak yang menulis dan berbicara tentang Pancasila sebagai dasar kehidupan bernegara dan falsafah kehidupan berbangsa bagi bangsa Indonesia. Karena itu rasanya tidak perlu penulis tambahkan dengan memberikan uraian tentang Pancasila sebagai falsafah berbangsa dan bernegara.

Yang ingin penulis sampaikan di sini adalah betapa luas dan dalam pemikiran founding parents kita pada 1940-an dengan menyetujui lima moral dan falsafah kehidupan bermasyarakat yang tidak hanya ideal bagi kehidupan berbangsa dan negara kita, tetapi sudah dianggap ideal oleh tokoh-tokoh umat manusia, jauh sebelum abad ke-20.

Ahli falsafah, Benedict Spinoza mengatakan tentang persamaan (hak hidup) manusia: "The highest good of those who follow after virtue is common to all, and all may equally enjoy it". ${ }^{13}$ (Hal yang paling berharga bagi mereka yang menjalankan kebajikan, juga dikejar (diinginkan) oleh semua orang, dan semua orang sama-sama boleh menikmatinya).

Pendapat Spinoza tersebut menunjuk pada asas peri kemanusiaan dan persamaan (hak) asasi manusia, diikuti oleh asas Ketuhanan yang Maha Esa, yaitu dengan mengatakan: "The good which everyone who follows after virtue seeks for himself he will desire for other men; and his desire on their behalf will be greater, the greater knowledge he has of God". ${ }^{14}$ (Kebaikan yang dikejar oleh orang bijak untuk dirinya sendiri, akan ia harapkan juga untuk orang lain; dan harapan atau keinginan ini semakin besar, sesuai dengan semakin meningkatnya pengenalannya kepada Tuhan).

13 Benedict Spinoza: "Ethics Wardsworth Classics of World Literature", terjemahan W.H. White, 2000, hlm 187. 14 Id. 
Spinoza menunjukkan secara gamblang betapa eratnya hubungan antara kepercayaan dan kepasrahan kepada (kehendak) Tuhan Yang Maha Esa dan keyakinan akan Hak Asasi Manusia dan nilai peri kemanusiaan. Khususnya, semakin tebal kepercayaan kita kepada Tuhan Yang Maha Esa, semakin besar pula kasih kita kepada manusia. Dengan perkataan lain, kasih kita kepada Tuhan Yang Maha Esa tersalur, antara lain, melalui kasih kita kepada sesama manusia, dan (dalam kaitan kehidupan berbangsa dan bernegara) kasih kita kepada sesama anak bangsa dan warga negara Indonesia.

Apabila apa yang kita inginkan untuk diri sendiri, juga diinginkan oleh orang lain, yang juga berhak 'memiliki' atau 'mencapai' apa yang diinginkannya itu, maka keadaan yang dituju itu adalah keadaan persamaan dan keadilan untuk semua, yang dalam bahasa sehari-hari kita sebut 'keadilan sosial'.

Sebagaimana diketahui istilah 'keadilan sosial' merupakan kata majemuk yang terdiri dari dua kata, yaitu 'keadilan' dan 'sosial', dapat diartikan secara bermacam-macam. Kita mengenal keadilan komutatif, yang menyangkut hubungan antara dua orang yang terikat oleh suatu kontrak, dan yang hak dan kewajibannya kurang lebih (harus) seimbang. Kita juga mengenal keadilan distributif, yang mengharuskan kepada warga negara untuk memberikan hak dan kewajiban yang sebanding kepada warga negaranya ${ }^{15}$, sesuai dengan kemampuannya. Sedangkan kata 'sosial' sering dipakai dalam arti 'untuk masyarakat' atau 'oleh masyarakat' atau 'mempunyai sifat kemasyarakatan'.

Tetapi, menurut Black's Law Dictionary, 'social justice concern obligations of individual to the community, which end is the common good'.16 (Keadilan sosial menyangkut kewajiban manusia perseorangan terhadap masyarakatnya yang bertujuan mencapai kebaikan bersama).

Dalam kaitannya dengan Indonesia, sebaiknya kita periksa Pembukaan Undang-Undang Dasar 1945 yang menyatakan, bahwa kita: "membentuk suatu

15 Black's Law Dictionary, 1991, hlm. 864.

16 Id. 
Pemerintah Negara Indonesia yang melindungi segenap bangsa Indonesia dan seluruh tumpah darah Indonesia, dan untuk memajukan kesejahteraan umum, mencerdaskan kehidupan bangsa, dan ikut melaksanakan ketertiban dunia yang berdasarkan kemerdekaan, perdamaian abadi dan keadilan sosial”. Dengan demikian, dalam Pembukaan Undang-Undang Dasar 1945 itu dipakai kata-kata 'kesejahteraan umum' dan 'keadilan sosial' dalam konteks kehidupan internasional dan global.

Selanjutnya dalam Pembukaan Undang-Undang Dasar 1945 dinyatakan: “..... maka disusunlah kemerdekaan kebangsaan Indonesia itu di dalam suatu Undang-Undang Dasar Negara Indonesia yang terbentuk dalam suatu susunan Negara Republik Indonesia yang berkedaulatan rakyat dengan berdasar kepada Ketuhanan Yang Maha Esa, Kemanusiaan yang Adil dan Beradab, Persatuan Indonesia, dan Kerakyatan yang Dipimpin oleh Hikmat Kebijaksanaan dalam Permusyawaratan/Perwakilan, serta dengan mewujudkan suatu keadilan sosial bagi seluruh rakyat Indonesia". Dalam konteks anak kalimat yang terakhir, keadilan sosial merupakan salah satu tujuan pembentukan Negara Kesatuan Republik Indonesia. Hal ini berarti, seluruh rakyat Indonesia maupun setiap anak bangsa dapat menikmati kehidupan yang aman, damai, cerdas, maju, sejahtera lahir batin, dan bahagia, sebagaimana kita mengharapkan kehidupan seperti itu bagi diri kita sendiri dan bagi anak keturunan kita.

Jika demikian, maka 'keadilan sosial' tidak hanya menunjuk pada kewajiban negara terhadap warga negara, tetapi juga menunjuk pada kewajiban kita sebagai perseorangan kepada masyarakat dan negara (fungsi sosial warga negara). Selanjutnya keadilan sosial itu tidak menyangkut kehidupan internasional dan global saja, tetapi terlebih-lebih tertuju pada kehidupan berbangsa dan bernegara secara internal. Di samping itu keadilan sosial tidak hanya menunjuk pada unsur kemakmuran atas aspek ekonomi saja, tetapi lebih dari itu mencakup keadilan dari aspek moral, hukum sosial/kemasyarakatan, 
kejiwaan rasional, dan lain sebagaimana yang dialami manusia di dalam segala kebutuhannya secara holistik.

Adapun cara mencapai kebahagiaan dan kesejahteraan umum atau aspek keadilan sosial itu adalah melalui proses pengambilan keputusan yang sesuai dengan budaya Indonesia, yaitu musyawarah untuk mencapai kata sepakat. Di dalam bahasa moderen sekarang, hal ini disebut 'negosiasi untuk mencapai winwin solution'.

Memang proses ini lebih lambat dari pada proses pengambilan keputusan melalui pemungutan suara terbanyak (atau sistem voting). Tetapi juga di dunia barat sekarang sudah diakui, bahwa cara ini jauh lebih baik dibandingkan sistem voting, yang adversarial (bertentangan) dan selalu menimbulkan fihak yang kalah di samping pihak yang menang.

Di sisi yang lain, dalam perkembangan bangsa, anak bangsa Indonesia tidak pernah mau mengaku kalah. Hal ini terbukti dari hasil-hasil Pemilu dan Pilkada, yang oleh pihak yang kalah suara selalu dianggap dan disebabkan karena telah terjadi kecurangan-kecurangan. Bagi orang Indonesia, kalah dalam pertarungan berarti telah dipermalukan, dan karena itu kalah atau menang merupakan masalah hidup dan mati.

Bagi orang barat, kekalahan merupakan "your stepping stone to success", atau batu loncatan ke arah sukses, sehingga kita tidak perlu malu kalau kita kalah. Sejalan dengan upaya untuk mencapai win-win solution, Perserikatan Bangsa Bangsa (PBB) sendiri telah lama menggunakan cara 'musyawarah untuk mufakat' dalam proses pengambilan keputusan.

Ironisnya, sementara bangsa-bangsa lain sudah mulai sadar akan nilai 'musyawarah untuk mufakat' atau mencapai 'win-win solution', bangsa Indonesia justru meniru apa yang oleh bangsa-bangsa lain dianggap kurang memadai.

Begitu pula dengan pembangunan sistem ekonomi nasional. Sementara negara-negara maju satu persatu meninggalkan sistem ekonomi liberal ala Adam Smith, Indonesia sejak 1980-an justru mulai menerapkan, sekalipun pasal 33 UUD 
1945 dengan gamblang memerintahkan: perekonomian disusun sebagai usaha bersama berdasar atas asas kekeluargaan; cabang-cabang produksi yang penting bagi negara dan yang menguasai hajat hidup orang banyak dikuasai oleh negara; bumi dan air dan kekayaan alam yang terkandung di dalamnya dikuasai oleh negara dan dipergunakan untuk sebesar-besarnya kemakmuran rakyat; dan perekonomian nasional diselenggarakan berdasar atas asas demokrasi ekonomi dengan prinsip kebersamaan, efisiensi, berkeadilan berkelanjutan, berwawasan lingkungan, kemandirian, serta dengan menjaga keseimbangan kemajuan dan kesatuan ekonomi nasional.

Asas-asas tersebut di atas yang merupakan asas-asas yang menjadi dasar pembangunan ekonomi nasional mirip dengan asas-asas yang dianut oleh Jerman pada 1950-an (soziale marktwirtschaft) atau Jepang setelah Perang Dunia Ke-2 melalui sistem human capitalism yang fokus pada keadilan sosial dan kebahagiaaan manusia dan tidak pada uang serta materi seperti sistem ekonomi liberal.

Apa yang diuraikan sebelumnya berkaitan dengan Pasal 33 UUD 1945, lebih diperjelas oleh Pasal 34 UUD 1945 yang menyatakan: fakir miskin dan anakanak yang terlantar dipelihara oleh negara; negara mengembangkan sistem jaminan sosial bagi seluruh rakyat dan memberdayakan masyarakat yang lemah dan tidak mampu sesuai dengan martabat kemanusiaan; dan negara bertanggungjawab atas penyediaan fasilitas pelayanan umum yang layak.

Apa yang tertuang di dalam Pasal 33 dan Pasal 34 UUD 1945 kiranya tidak terlepas dan berkaitan erat dengan Pasal 27 UUD 1945, ayat 1, dan 2, serta Pasal 28A UUD 1945 yang menyatakan: segala warga negara bersamaan kedudukannya di dalam hukum dan pemerintahan dengan tidak ada kecualinya; dan tiap-tiap warga negara berhak atas pekerjaan dan penghidupan yang layak bagi kemanusiaan. Sementara Pasal 28A, mempertegas, bahwa setiap orang berhak untuk hidup serta berhak mempertahankan hidup dan kehidupannya. 
Membaca kembali sila-sila Pancasila, Pembukaan UUD 1945 dan berbagai pasal di dalam UUD 1945, termasuk yang sudah diamandemen, tampaklah betapa luas, modern dan sangat mulia falsafah hidup berbangsa dan bernegara bangsa Indonesia yang sejak pertama eksistensinya, yaitu tanggal 18 Agustus 1945, sudah dicantumkan dengan huruf emas di dalam Pembukaan atau Preambul UndangUndang dasar 1945.

Dari manapun kita mulai meninjau, baik dari sila Ketuhanan Yang Maha Esa, ataukah dari sila Keadilan Sosial, atau sila Peri Kemanusiaan, sila Persatuan Bangsa, maupun Musyawarah untuk mufakat, setiap sila atau nilai itu akan bertemu atau berkaitan dengan sila-sila yang lain, sehingga kelima sila dari Pancasila ini sesungguhnya merupakan satu falsafah yang utuh menyeluruh (holistik) tentang kehidupan berbangsa, bernegara, dan bermasyarakat, dan yang dapat dan harus diterapkan dan digunakan dalam setiap situasi yang kita hadapi, dan untuk setiap masalah yang harus kita pecahkan.

Hal yang menarik, justru di abad globalisasi di abad 21 ini, di mana kita sebagai negara berkembang harus menghadapi berbagai pilihan untuk survival pribadi maupun sebagai sebuah bangsa, ketika kita wajib meningkatkan pemberdayaan sumber daya manusia serta pengalaman kelangsungan lingkungan dan lebensraum (ruang kehidupan) kita, baik sebagai individu, apalagi sebagai bangsa, falsafah Pancasila itulah yang paling besar kemungkinannya memungkinkan bangsa Indonesia bertahan dalam pertarungan antar bangsa. ${ }^{17}$ Sehingga Pancasila itulah yang sudah tepat menjadi kompas bagi pembangunan bangsa dan negara di abad ke 21 ini.

\section{Budaya Hukum Indonesia}

Lawrence Friedman, yang pertama-tama mengemukakan dan membahas tentang konsep 'budaya hukum' atau 'legal culture', mengatakan: 'legal culture

\footnotetext{
${ }^{17}$ Bandingkan: H.B. Maynard, Jr. \& Susan E. Mehrtens: “The Fourth Wave”, Berret-Koehler Pub, San Francisco, Robert Ozaki, "Human Capitalism”, Kodamsha Internasional Tokyo, New York, London. 1991 yang mengatakan di halaman 181, dan selanjutnya: "The twenty-first century will witness the prevalence of a people-oriented economic system in one from or other".
} 
determines when, why and where people turn for help to law, or to other institutions, or just to decide to 'lump it"'.18 (budaya hukum menentukan kapan, mengapa dan ke mana orang akan pergi untuk meminta bantuan hukum, atau lembaga-lembaga lain (untuk memperoleh keadilan), atau hanya 'membiarkannya saja').

Lawrence Friedman juga membedakan antara budaya hukum internal, yang menyangkut praktik-praktik dan kebiasaan para profesi hukum, dan budaya hukum eksternal, yang menyangkut opini, kepentingan dan tekanan-tekanan terhadap hukum oleh kelompok masyarakat itu sendiri, khususnya mengenai seberapa besar masyarakat pada umumnya menuntut atau menghendaki penyelesaian melalui jalur hukum. ${ }^{19}$

Apabila kita menggunakan kriteria yang digunakan oleh Lawrence Freidman, maka dapat dikatakan, bahwa kurang lebih 20 tahun terakhir, mungkin sebagai reaksi dari masalah-masalah pelanggaran hak asasi manusia di masa Orde Baru, lebih sering terdengar tuntutan masyarakat untuk menyelesaikan suatu masalah "melalui jalur hukum", sesuai dengan asas negara hukum atau the rule of law (supremasi hukum).

Tendensi tersebut merupakan hal yang positif dan menunjuk pada semakin kuatnya kesadaran akan kebenaran nilai persamaan, hak hidup dan hak asasi manusia, sesuai dengan sila peri kemanusiaan, dan bahkan juga sila Ketuhanan Yang Maha Esa, serta sila Keadilan Sosial. Namun, perkembangan budaya hukum eksternal ini tidak diimbangi oleh budaya hukum internal para pengemban profesi hukum dan lembaga-lembaga hukum Indonesia.

Pengacara Indonesia terlalu sering mengandalkan kekuatan uang untuk memenangkan perkara, dan sebenarnya terlalu sering menyalahgunakan penguasaan ilmu hukum untuk menyimpang dari makna dan tujuan hukum itu sendiri, guna memenangkan perkara.

\footnotetext{
${ }^{18}$ Lawrence Friedman: "The concept of legal culture: A. Reply" dalam buku David Nelken (ed), 1997, hlm. 33-40.

${ }^{19}$ Baca "melalui pengadilan".
} 
Para panitera pengadilan dan para hakim pengadilan-pun sudah terlalu sering bertekuk-lutut pada iming-iming uang dan hidup mewah serta lupa, bahwa ia ditempatkan di kursi panitera atau hakim bukan sekadar untuk mencari nafkah, tetapi untuk mengemban suatu misi, yaitu agar setiap orang, setiap warga negara, kaya maupun miskin, pandai maupun bodoh, pria maupun wanita, anak kecil maupun kakek atau nenek, orang desa maupun orang kota, warga negara Indonesia maupun warga negara asing, semuanya akan memperoleh keadilan. Tidak hanya sesuai ketentuan-ketentuan harafiah pasal-pasal di dalam undangundang, tetapi terlebih-lebih sesuai dengan rasa keadilan, kepatutan, dan kewajaran, berdasarkan pertimbangan hakim yang bijaksana seimbang dan berperikemanusiaan yang bersumber pada persatuan bangsa dan ajaran Tuhan Yang Maha Esa.

Juga para jaksa dan polisi begitu mudah tergiur oleh tumpukan uang, dan lupa, bahwa apapun yang ia lakukan sehari-hari adalah untuk dan atas nama Negara Kesatuan Republik Indonesia, sehingga jika ia menganiaya seseorang, ia melakukannya atas nama Negara Kesatuan Republik Indonesia. Jika menerima suap, maka hal tersebut dilakukan juga atas nama Negara Kesatuan Republik Indonesia, sehingga Republik ini menjadi penerima suap, penjahat atau bahkan pembunuh akibat perbuatan terkutuk oknum jaksa dan/atau polisi.

Demikianlah sesuatu yang acap terjadi di dalam masyarakat, dan masih banyak realitas lainnya yang membuktikan, bahwa yang sangat buruk dan perlu diperbaiki adalah justru budaya hukum Indonesia, khususnya budaya hukum internal Indonesia, yaitu budaya hukum para pengemban profesi hukum, budaya hukum sumber daya manusia di dalam lembaga-lembaga hukum, seperti kepolisian, kejaksaan, lembaga para pengacara, notaris, para panitera pengadilan, para hakim pengadilan, dari Pengadilan Negeri sampai dengan Mahkamah Agung, dan Mahkamah Konstitusi. Tetapi juga termasuk di dalamnya para dosen dan guru besar, yang tanpa mempertimbangkan kemampuan mahasiswanya meluluskan mereka begitu saja, sebagai Sarjana Hukum. Padahal ia tidak cukup dibekali 
dengan ilmu hukum, dengan moral dan budaya hukum untuk dapat mengemban tugas "atas nama KeTuhanan Yang Maha Esa”, atau "atas nama Negara Kesatuan Republik Indonesia” yang berdasar kepada Pancasila.

Demikian juga para anggota Majelis Permusyawaratan Rakyat (MPR) dan Dewan Perwakilan Rakyat (DPR) atau Dewan Perwakilan Rakyat Daerah (DPRD), serta para penyelenggara negara lainnya, yang menyusun Undang-Undang Dasar serta peraturan Hukum Nasional kita, sampai kepada keputusan-keputusan lembaga pemerintah "untuk dan atas nama” Negara Kesatuan Republik Indonesia, dengan santainya melalaikan kewajibannya dan mempertunjukkan moral dan budaya yang buruk dengan tanpa malu menerima "honorarium tambahan" untuk pekerjaan atau tugas yang mestinya sudah merupakan tugas sehari-harinya, dan untuk itu sudah menerima honorarium yang tinggi dan fasilitas yang memadai.

\section{Peranan Pendidikan Tinggi Hukum dalam Memperbaiki Budaya Hukum Internal maupun Eksternal}

Jika demikian, maka untuk mengembalikan wibawa hukum di negeri ini, lepas dari materi atau kaidah apapun yang akan dimasukkan ke dalam sistem hukum nasional, yang akan dan harus dilakukan adalah memperbaiki budaya hukum internal, terutama memperbaiki moral dan perilaku (behaviour) para profesi hukum, baik yang sudah menjadi Sarjana Hukum, tetapi juga terlebih mereka yang belum menjadi Sarjana Hukum.

Karena itu, yang harus diukur dalam setiap tingkat ujian mahasiswa bukan hanya penguasaan mata kuliah ilmu hukum saja, tetapi yang sangat penting adalah mengukur bagaimana sikap atau pilihan moral dan etikanya di dalam suatu situasi hukum yang cukup rumit.

Artinya yang harus diukur dan diuji bukan hanya penguasaan peraturan dan/atau pasal-pasalnya, tetapi terutama pilihan moral dan sikap suatu pertimbangan etisnya dalam suatu situasi yang mengandung konflik moral, sehingga orang yang memutuskan apa yang harus dilakukannya benar-benar 
dapat mempertanggungjawabkan pilihannya itu secara etis dan bermoral berdasarkan falsafah kenegaraan yang dianut bangsa kita ini.

Konsekuensi dari semua ini adalah bahwa mata kuliah Filsafat Hukum harus benar-benar dikaitkan dengan pembahasan Etika Hukum yang dipermasalahkan oleh setiap aliran Filsafat Hukum, misalnya, apa sebenarnya yang merupakan inti filsafat hukum yang dianut Socrates tentang "kekuasaan", "kebenaran" dan "keadilan" dan sebagainya dibandingkan dengan Hobbes atau filsafat Macchiavelli, atau Spinoza atau Locke, Rousseau atau von Savigny, Roscoe Pound, Soepomo, Soediman, Bismar Siregar, Mochtar Kusumaatmadja, dan masih banyak lagi.

Manakala kesalahan penegakan hukum dan pembangunan hukum terletak pada budaya hukum internal, maka yang bersalah dalam pembangunan hukum itu adalah para pengemban profesi hukum itu sendiri, yang tidak dapat dibanggakan. Hal ini berbeda misalnya antara generasi sarjana hukum Inggris, Perancis, Belanda, Amerika, Jepang, Korea, Singapura, dan generasi Sarjana Hukum Indonesia pada permulaan abad ke-20.

Oleh sebab itu jelaslah, bahwa membenahi hukum nasional Indonesia, dalam berbagai arti dan bentuknya ${ }^{20}$, harus dimulai dengan membenahi lembagalembaga hukum itu sendiri dari dalam melalui proses dan program reformasi lembaga-lembaga hukum. Dari Majelis Permusyawaratan Rakyat, Dewan Perwakilan Rakyat, Mahkamah Konstitusi, Mahkamah Agung, dan semua badanbadan pengadilan, termasuk Pengadilan Militer dan Pengadilan Agama, serta quasi pengadilan, Kejaksaan Agung dan seluruh lembaga kejaksaan, kepolisian, dan para panitera dan panitera pengganti, para juru sita, lembaga pelelangan, dan semua Asosiasi Pengacara dan Penasehat Hukum, para notaris dan termasuk reformasi sistem Pendidikan Tinggi Hukum dan Fakultas Hukum.

20 Baca Sunaryati Hartono: "Politik Hukum Menuju Satu Sistem Hukum Nasional", Alumni, Bandung, serta, "Bhineka Tunggal Ika sebagai Asas Hukum Nasional”, Citra Aditya Bakti, Bandung, 2006, hlm. 41. 
Dalam proses ini, lembaga-lembaga pendidikan tinggi hukum, khususnya fakultas hukum mempunyai peranan yang sangat penting sebagai "produsen" profesi hukum kita di masa depan.

Memang benar, begitu banyak Ilmu Hukum baru dan metode-metode Penelitian Hukum baru yang masih harus diajarkan dalam rangka mengejar ketertinggalan Sarjana Hukum Indonesia dengan sarjana hukum asing dan sarjana-sarjana ilmu yang lain. ${ }^{21}$ Namun, ilmuwan yang sangat pandai, tetapi tidak bermoral ternyata mampu merusak kehidupan seluruh masyarakat menjadi tidak sesuai lagi dengan martabat kemanusiaan manusia, sehingga tidak kita perlukan di Indonesia. Dalam bahasa Belanda dikenal andagium "hoe groter geest, hoe groter beest" (semakin pandai seseorang, semakin timbul naluri kebinatangannya).

Satu hal yang penulis sesalkan ialah apabila peningkatan kecerdasan bangsa, sebagaimana diupayakan dalam Pembukaan UUD 1945 menjadi tujuan berbangsa dan bernegara, ternyata hanya akan menghasilkan manusia-manusia dan pengemban profesi hukum yang pandai, tetapi kejam dan tidak manusiawi, tidak berpegangan pada ajaran Tuhan Yang Maha Esa, melupakan mengapa kita semua, sebagai keturunan para pejuang kemerdekaan Indonesia, menjadi satu bangsa, bangsa Indonesia, yang telah bertekad untuk bekerja keras mencapai keadilan sosial untuk seluruh bangsa dan setiap warga negara di muka bumi ini.

Semuanya itu hanya untuk mengejar kekayaan (hedonisme) yang tidak halal untuk lebih dari 7 (tujuh) turunan, karena terseret keserakahan arus globalisasi dan pengaruh falsafah kapitalisme tradisional, yang nota bene menurut George Soros dan pemilik modal lainnya, sedang menghembuskan nafasnya yang

21 Bandingkan: Michiel Otto, di mana beliau mengatakan bahwa untuk pembangunan hukum penguasaan metode penelitian multidisipliner, khususnya antara hukum, ilmu hukum dan manajemen pemerintahan serta ilmu-ilmu sosial budaya, dan lingkunan merupakan suatu keharusan. 
terakhir ${ }^{22}$, dan karena itu masih bersikukuh menguasai seluruh dunia melalui perusahaan-perusahaan trans-nasional dan pasar-pasar modal.

\section{Penutup}

Sistem hukum nasional yang diidam-idamkan oleh para Founding Parents Indonesia, lebih dari 60 tahun yang lampau belum juga terbentuk, karena banyak di antara warga negara Indonesia belum sadar akan arti dan konsekuensi berbangsa Indonesia.

Akibatnya, kepastian hukum yang telah lama didambakan oleh bangsa Indonesia, masih jauh dari harapan. Sebaliknya, ketidakpastian hukum itulah yang akhir-akhir ini semakin menghambat terbentuknya negara hukum dan negara kesejahteraan yang riil/nyata. Padahal kepastian hukum yang riil/nyata menjadi pra-kondisi bagi pembangunan nasional di segala bidang.

Yang menyulitkan pembangunan hukum nasional itu adalah kecenderungan kebanyakan sarjana hukum kita sendiri yang hanya melihat hukum sebagai kaidah atau norma hukum belaka. Padahal baik Lawrence Friedman, Jan Michiel Otto, Daniel Lev dan banyak sarjana hukum asing maupun Indonesia memandang hukum sebagai sistem, yang terdiri dari sekian banyak faktor yang saling pengaruh-mempengaruhi. Secara mutatis mutandis, manakala salah satu faktor dalam sistem hukum itu akan diubah, maka seluruh faktor-faktor lainnya dari sistem hukum itu harus diubah pula.

Akibatnya semakin lama menunda pembentukan sistem hukum nasional, semakin sulit dan semakin panjang waktu yang diperlukan untuk proses pembentukan hukum nasional dan pembangunan di segala bidang. Pada 1940-an, misalnya dunia yang baru bangkit dari Perang Dunia ke-2 lebih menghormati kedaulatan negara-negara nasional, sehingga pada saat itu pengaruh hukum internasional tidak terlalu berperan dibandingkan 3-4 dasawarsa terakhir, ketika

22 Baca George Soros: "The crisis of global capitalism", public affair, New York, 1998, juga Robert Ozaki: "Human Capitalism", Kodansha International, Tokyo, 1991, dan Yoshihara Kunio: "Globalization and National Identity, Falcon Press, Petaling Jaya, 2001, serta Heinz Lampert: "Ekonomi Pasar Sosial" (Soziale Marktwirtschaft), Puspa Swara, 1994. 
arus globalisasi sudah mulai merambah kedaulatan negara-negara nasional dengan semboyan satu dunia untuk semua. Oleh sebab itu kiranya, program pembentukan sistem hukum nasional termasuk reformasi sistem peradilan dan reformasi birokrasi, dan sekian banyak program reformasi, termasuk reformasi pendidikan tinggi hukum perlu dilakukan dan diselesaikan secepat mungkin.

Bagaimanapun juga, karena segala usaha dan upaya tergantung dari mutu intelektual maupun mutu moral dan integritas manusia yang harus mengerjakannya, maka tugas utama terletak di lembaga-lembaga sektor pendidikan tinggi di satu pihak, dan di pundak para pendidik dan orang tua untuk mengembangkan kesadaran berbangsa Indonesia dan budaya bangsa Indonesia yang bersumber pada falsafah Pancasila, terutama kepada mereka yang akan menjadi pengemban profesi hukum.

\section{Daftar Pustaka}

\section{Buku}

Berge, JB. JM ten, et al. (ed), Recht als norm en als aspirate, Ars Aqui Libri, Nijmegen, 1986.

Fukuyama, Francis, Trus: The Social Virtues and The Creation Of Prosperity, Hamish Hamilton, London, 1995.

Hartono, Sunaryati, Apakah The Rule Of Law itu?, Alumni, Bandung, 1969.

Indonesia, Alumni, Bandung, 1996.

, Bhineka Tunggal Ika sebagai Asas Hukum Bagi Pembangunan Hukum Nasional, Citra Aditya Bakti, Bandung, 2006.

Holt, Claire (ed), Culture and Politics in Indonesia, An Equinox Classic Indonesia Book, Equinox Publishing, Jakarta, 2007.

Kunio, Yoshihara, Globalization and National Identity, Falcon Press, Petaling Jaya, 2001.

Lampert, Heinz, Ekonomi Pasar Sosial, Puspa Swara, Jakarta, 1994.

Langbroek, Ph.M., Ombudsprudentie, Boom Juridische Uitgevers, \& Rijpkema, P (ed), Den Haag, 2004.

Lev, Daniel, Judicial Institutions and Legal Culture in Indonesia (dalam Holt, C: Culture and Politics in Indonesia).

Machiavelli, The Prince, Wardsworth Classics of World Literature, 1997. 
Maynard, Herman Bryant Jr \& Mehrtens, Susan E, The Fourth Wafe, BerrethKoehler Publisher, San Francisco, 1993.

Nice, Richard W (ed), Treasury of the rule of law, Little Field, Adams \& Co, 1965.

Otto, Jan Michiel, Reele Rechtszekerheid In Ontwikkeling-sladen, Universiteit Leiden, 2000.

Ozaki, RobertS, Human Capitalism, Kodamsha International.

Plato, Republic, Wardworth Classic of World Literature, 1997.

Prins, Winkler, Elsevier, 1950 (tentang Ethiek, Recht dan Rechtsfilosofie).

Renan, Ernest, Qu'est ce qu'une nation? Terjemahan Sunario.

Rivera, David Allen, The World Order Exposed, Thinker's Library, 1997.

Rizky, Rudy (ed), Refleksi Dinamika Hukum: Rangkaian Pemikiran dalam Dekade Terkahir, Cetakan Negara RI, 2008.

Spinoza, Benedict, Ethics, wardsworth classics of world literature, 1997.

Soros, George, The Crisis of Global Capitalism, Public Affair, New York, 1998.

Vickers, Adrian, A History of Modern Indonesia. Cambrige University Press, 2005.

Whirter, Darien, A. Mc., The Legal 100, Coral Publishing, 1998.

Wowor, Ben, Se-abad Lingkungan Saya, Manado, 2007

Lain-lain:

Black's Law Dictionary, Sixth Edition, 1991. 